\title{
DETERMINATION OF PERIODICITY OF INSTRUMENTAL EXAMINATIONS SUBJECT TO EXPENDITURES FOR OPERATION OF MEASURING SYSTEMS
}

\section{Hryhorovskyi P. Ye.}

\section{INTRODUCTION}

An important problem in studies of natural and man-caused processes during construction and operation of buildings is an investigation of interference between construction activities, surrounding territories and adjacent developed areas. Defects and damages of buildings that have been untimely detected result in material losses, damages to society and environment. Therefore it is necessary to evaluate the state of buildings in proper time, predict a possible trend in the development of defects and damages and establish measures for their stabilization or removal. For this purpose a better understanding of mechanisms of destruction and deterioration of structural elements during construction and operation and capability to evaluate the effects of environmental factors are needed. And such an understanding and capability are impossible without actual data obtained by instrumental measurements. The instrumental measurements are integral parts of technological processes at all stages of the building life cycle and affect their organizational-technological and technical indices. Therefore the determination of periodicity of instrumental examinations subject to expenditures for operation of measuring systems is an urgent scientific and technical issue.

\section{Determination of periodicity of activities on performing instrumental examinations}

Generally, the periodicity of planned examinations is specified on the basis of data on buildings under average service conditions. According to recommendations specified in the works ${ }^{1,2}$ the terms of examinations should be established with an allowance for a level of safety that is characterized by reliability, ecological safety and corrosiveness of environment, structural

1 Ivanyk I.H. Principles of reconstruction of buildings and structures / I.H. Ivanyk, S.I. Vikhot', R.S. Ivannyk, Yu.Yu. Vybranets'; ed. I.H. Ivanyk. - L'viv: Publishers L'viv Politekhnika, 2010. - 276 p. (in Ukrainian).

${ }^{2}$ Normative documents on issues of examinations, certifications, safe and reliable operation of production buildings and structures. - K.: NDIBV, 2003. - 144 p. (in Ukrainian). 
features, and characteristics of bases, availability of stationary instrumentation, experience in operation of similar buildings. The periodicity of planned examinations $T_{n}$ is specified on the assumption of a possibility to maintain the facility service conditions until the next examination and expressed as

$$
\mathrm{T}_{\mathrm{\Pi}}=\mathrm{T}_{6} \cdot \mathrm{K}_{6}
$$

where $T_{6}$ is the term until the first planned examination for buildings under average conditions of operation;

$\mathrm{K}_{\sigma}$ is the safety factor defined by expression

$$
\mathrm{K}_{6}=\gamma_{\mathrm{n}} \cdot \mathrm{K}_{\mathrm{eK}} \cdot \mathbf{K}_{\mathrm{ar}}
$$

where $\gamma_{n}$ is the reliability factor for purpose, it numerically characterizes a degree of reliability of buildings and varies from 1,25 (the most reliable structures) to 0,8 (the least reliable structures);

$\mathrm{K}_{\mathrm{eK}}$ is the coefficient that characterizes the environmental unsafety of production and varies from 0,8 (unsafe production) to 1,0 (safe production);

$\mathrm{K}_{\mathrm{ar}}$ is the coefficient of environment corrosiveness effect that varies from 0,7 (heavy corrosive environment) to 1,0 (non-corrosive environment).

In our opinion the above method is lacking in recommendations with respect to the correction of $T_{6}$ values. The average service conditions may be justified when statistic data for a great number of buildings of the same type under similar operating conditions are available. And the measuring equipment is only available if it has been specified in the project. The recommendations don't account for dynamical changes in building operating conditions and their consequence class. Though the safety factor can characterize the class of consequences but according to (2) it characterizes the degree of stability and reliability namely for the higher degree the period between examinations is longer. To account for the class of consequences the level of responsibility shall be increased and the period of examinations shall be simultaneously shortened. It is difficult to predict variations of material properties in time for a long-term period without statistical or laboratory tests for ageing processes which are complicated by service conditions. 
The method for determination of structure maintenance periodicity on the basis of data on structural reliability (failure rate) ${ }^{3}$ provides for determination of the maintenance and repair periodicity $t_{\text {пр }}$ at which the probability of no-failure operation is less than a specified value $\mathrm{P}<1$.

$$
\mathrm{P}\left(\mathrm{t}_{\text {пр }}\right)=\mathrm{e}^{-\lambda \mathrm{t}_{\text {пр }}} \text {, }
$$

where $\lambda$ is the failure rate.

To simplify calculations it is anticipated that after $t_{\text {пр }}$ the capacity for work will be immediately renewed in full and a new countdown of the service life will begin. In this case a change in the failure probability $\mathrm{Q}$ during operation is shown in Fig. 1.

If $\mathrm{P}_{0}$ is a probability of no-failure operation then the following condition shall be true

$$
\mathrm{P}\left(\mathrm{t}_{\text {пр }}\right)=\mathrm{e}^{-\lambda \mathrm{t}_{\text {пр }}} \geq \mathrm{P}_{0}
$$

Then if follows

$$
\frac{\mathrm{t}_{\text {пр }}}{\mathrm{t}_{\text {cep }}} \leq-\ln \mathrm{P}_{0},
$$

where $t_{\text {cep }}=\frac{1}{\lambda}$ is a mean time between failures;

$\lambda$ is a failure ratio.

Thus if $P_{0}=0,9$ then $t_{\text {пр }} \leq 0,105 \cdot t_{\text {сер }}$. That is for ensuring the $90 \%$ probability of no-failure operation it is necessary to perform the repair operations which renew operating conditions in full ten times. If an actual time of renewal of the capacity for work is accounted for the calculations are more complex but this does not affect the result. This method only accounts for statistic data on a mean time between failures but such data are not available in the construction industry. Any class of consequences and foundation features are not accounted for in the method for determination of periodicity. The above method for determination of periodicity may be only used during the period of regular operation when the failure rate is stable. In

\footnotetext{
${ }^{3}$ Petrov E.G. Methods and means for making decisions in economic and technical systems / E.G. Petrov, M.V. Novozhilova, I.V. Grebennik, N.A. Sokolova; under the general editorship of E.G. Petrov. - Kherson: OLDI-plus, - 2003. - 378 p. (in Russian).
} 
arranging a deformation monitoring system this fact may introduce errors in the validity of obtained data or result in an increase of cost of measuring operations.

In our opinion, an algorithm of determination of periodicity of instrumental examinations of structures shall be based on the same principles namely on the comparison of controlled parameters $\Pi_{\mathrm{i}}$ with the estimated (predicted) values $\Pi_{\mathrm{i}}^{\prime}$.

The maximum allowed value of the controlled parameter $\Pi_{i}$ is defined as follows

$$
\Pi_{\max }=\Pi_{i}^{\prime}+\Delta \Pi_{i}
$$

where $\Delta \Pi_{i}$ is the range of possible allowable deviations of the controlled parameter $\Pi_{\mathrm{i}}$.

Estimated values $\Pi_{i}^{\prime}$ are determined on the basis of mathematical modelling and adjusted as part of the research and development support of construction. The maximum allowable value of parameter $\Pi_{\max }$ is calculated at the stage of designing and also adjusted while performing the research and development supporting work. The rate of changes in parameter $\Pi_{i}$, which equals $\mathrm{V}=\frac{\Delta \Pi}{\Delta \mathrm{t}}$, is determined at the stage of designing and adjusted in accordance with the results of instrumental examinations. The maximum allowable values of parameter $\Pi_{\max }$ shall ensure an opportunity for conducting measures directed on maintaining the serviceability of buildings.

At that $\mathrm{T}_{\text {мон.max }}$ (Fig. 2) is the maximum allowable duration of the examination period which should ensure detection of the onset of damages in proper time before the date after which the renewal of the design operating conditions will become impossible. The maximum duration of this term shall be specified on the basis of the maximum deviation of parameter $\Delta \Pi_{\mathrm{B}}$ which may be determined at the specified measurement error $\sigma_{\mathrm{B}}$ that shall comply with the relation $\sigma_{\mathrm{B}} \geq 0,2 \Delta \Pi_{\mathrm{B}}$. In such a case the monitoring will ensure timely detection of parameter deviation at the specified inaccuracy of the measuring system

$$
\mathrm{T}_{\text {мон. } \max }=\Delta \Pi_{\mathrm{B}} / \mathrm{V}=5 \sigma_{\mathrm{B}} / \mathrm{V}
$$




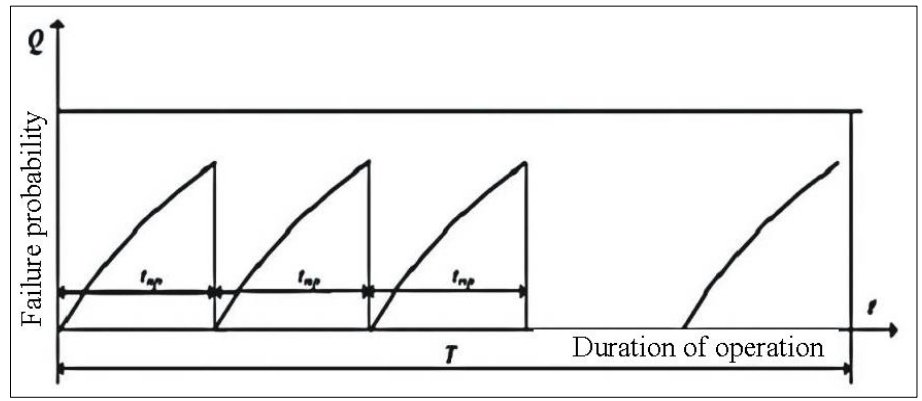

Fig. 1. Curve of changes in failure probabilities:

$t_{n p}$ - time of renewal of functional qualities

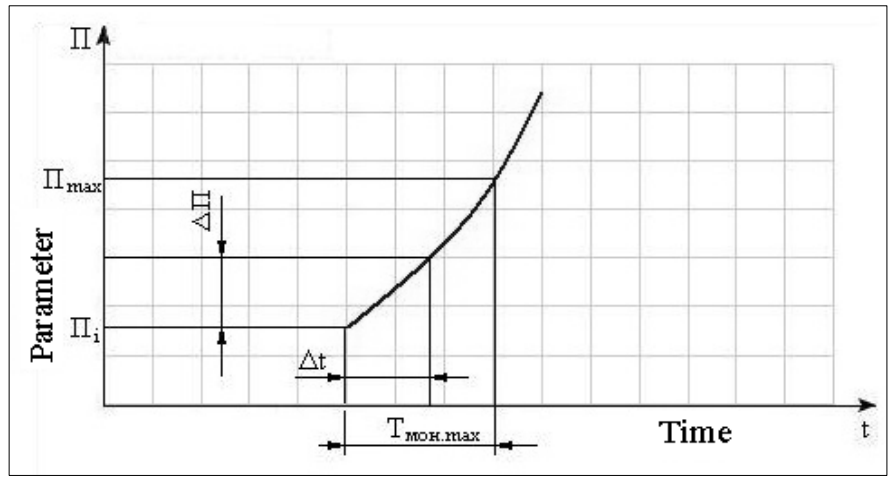

Fig. 2. Determination of the maximum period of instrumental examinations

\section{Periodicity of examinations subject to the terms of repair and restoration work}

The greatest number of accidents occurs within the first 10-15 years of operation. During these accidents design and work performance errors are detected. According to the statistic data more than $32 \%$ of accidents occur at facilities whose term of operation does not exceed 10 years (Fig. 3). Percentage of accidents at buildings and structures of more than 40 years old is less than this indicator for "younger" structures by a factor of six. Then, until the 70-year term of operation a period of relatively even distribution of structure life-limiting failures lasts. The causes of failures are design or work performance errors, application of ineffective materials due to increased costs and profits. 
Taking into account the great number of accidents during the initial stage of operation of structures let's apply the following expression that describes the time behavior of deterioration to determine the terms of repair and restoration work

$$
3=\lambda \sqrt{\mathrm{t}}
$$

where 3 is the building deterioration, \%;

$\lambda$ is the coefficient that characterizes the rate of deterioration;

$\mathrm{t}$ is the service lifetime, years.

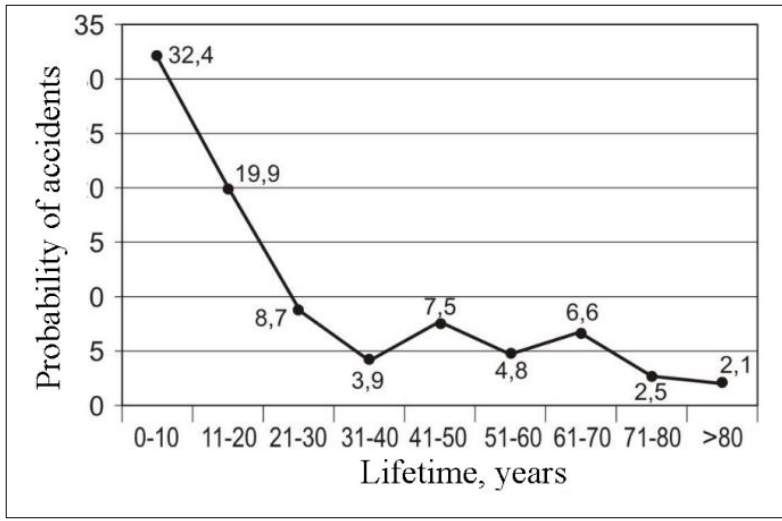

Fig. 3. Accidents with buildings against their lifetime

For buildings with the standard lifetime of 100 years let's assume the value of deterioration as $100 \%$. In this case the coefficient is

$$
\lambda=\sqrt{\frac{3^{2}}{\mathrm{t}}}=0,1
$$

Figure 4 shows the time behavior of building deterioration for such data. For this function the rate of deterioration at the initial stage of operation is defined as the first derivative of the function

$$
\mathrm{I}=\frac{\mathrm{d} 3}{\mathrm{dt}}=\frac{\lambda}{2 \sqrt{\mathrm{t}}}
$$


The plot of the first derivative is shown in Fig. 5. According to the plot the rate of deterioration at the initial stage of operation exceeds this indicator for the period of overhaul after 24 years by a factor of about 5 that corresponds with the statistic data on accident rates of buildings (see Fig. 3). On the basis of the assumption that at the deterioration of $41 \%$ the buildings are considered as unserviceable we can determine the execution period for overhauls $T_{к р}$ (Fig. 4). At the overhaul execution period of $T_{\mathrm{kp}}=16$ years and the service lifetime of $T_{e}=100$ years the number of overhauls is

$$
\mathrm{n}_{\text {кр }}=\frac{\mathrm{T}_{\mathrm{e}}}{\mathrm{T}_{\text {кр }}}=\frac{100}{16}=6,25 .
$$

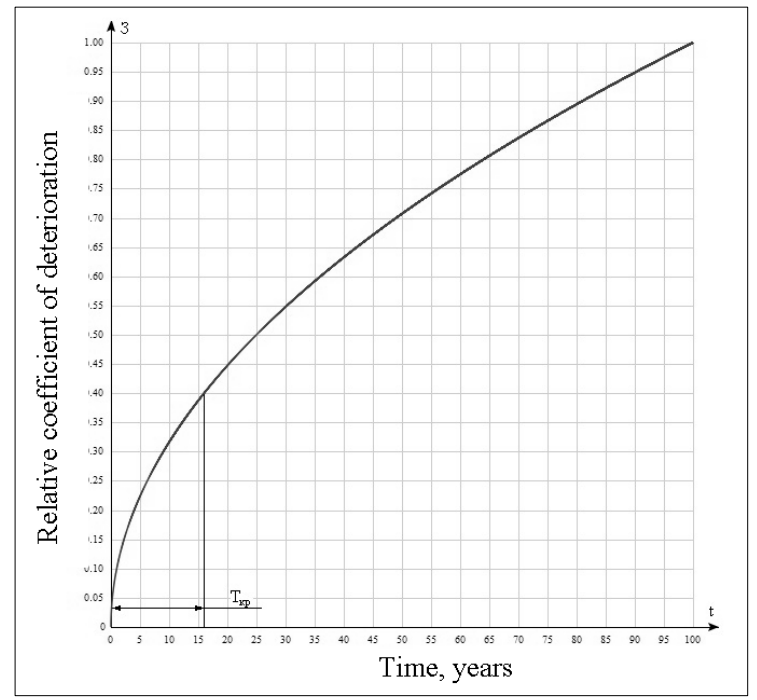

Fig. 4. Plot of building deterioration against time

Let's assume $\mathrm{n}_{\mathrm{кр}}=6$ for the whole period of lifetime and the residual building deterioration of $3_{3}=2,5 \%$ during overhaul. The dependence of building deterioration against time at the periods of overhaul is shown in Fig. 6 where the reduced building deterioration during the overhauls is taken into consideration and the overhaul periods are grouped by similar service lives of structures and conducted every 3-5 years. The data on the dependence of the terms of overhauls against the service lives are presented in Table 1. 
Table 1

Terms of overhauls

\begin{tabular}{|c|c|c|c|}
\hline $\begin{array}{c}\text { Standard service } \\
\text { lifetime, years }\end{array}$ & $\mathbf{1 0 0}$ & $\mathbf{6 0}$ & $\mathbf{5 0}$ \\
\hline$\lambda$ & 0,1 & 0,129 & 0,141 \\
\hline$T_{\kappa n . m i n}$, years & 16 & 10 & 8 \\
\hline \multicolumn{4}{|c|}{ Note: $T_{\kappa n}$ is the term of overhaul $(3=40 \%)$} \\
\hline
\end{tabular}

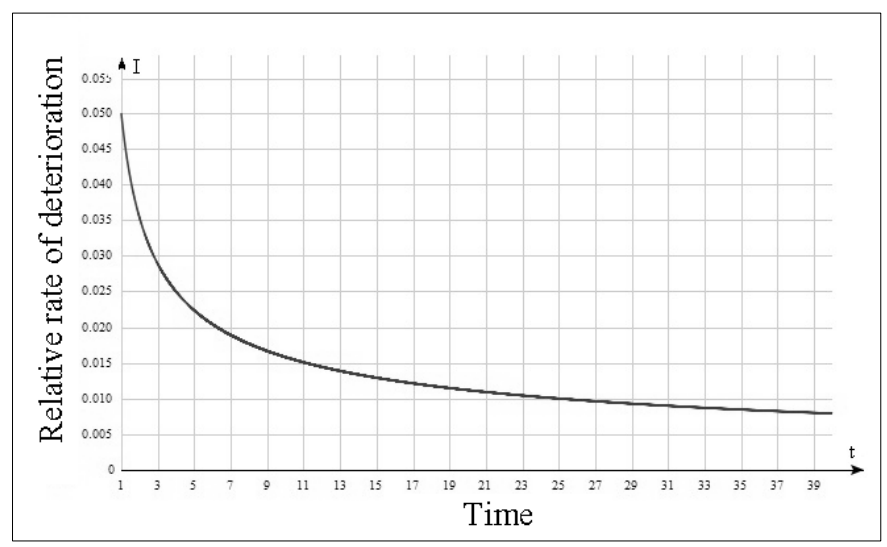

Fig. 5. Rate of deterioration vs. time

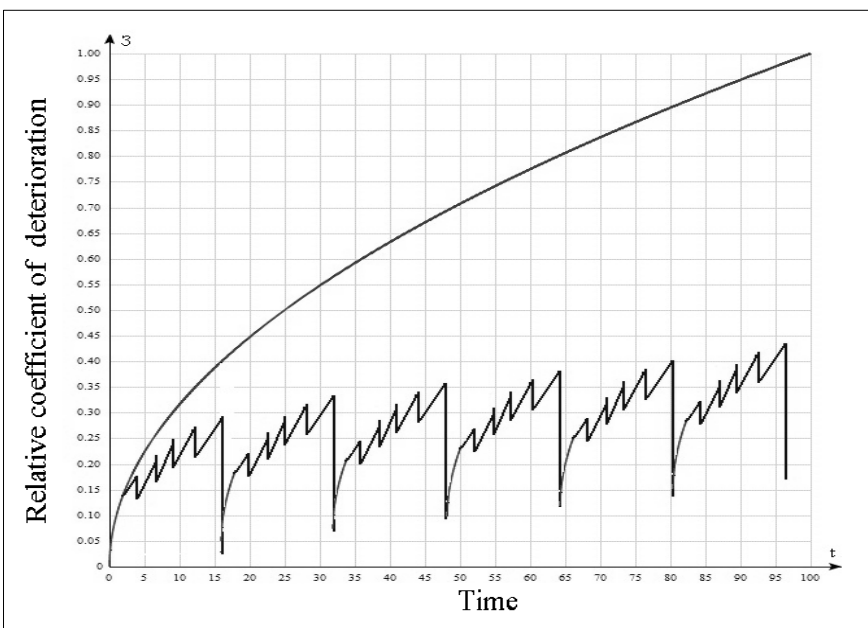

Fig. 6. Building deterioration vs. time during overhauls 
The method does not account for the level of building safety that is characterized by reliability, environmental safety and effects of corrosive environment. Nevertheless the application of coefficient $K_{\sigma}$ (2) for correction of the term of examination $T_{k n \text { min }}$ will allow accounting these factors as well

$$
\mathrm{T}_{\text {кр }}=\mathrm{T}_{\text {кп. min }} \cdot \mathrm{K}_{\text {б }}
$$

As repair operations are always performed after the examinations whose purpose is a determination of a scope of such operations the method used for determination of the terms of building repairs may be applied for defining the terms of instrumental examinations.

\section{Periodicity of settlement control operations at the initial stage of building life cycle and in the process of operation}

In establishing the periodicity of examinations the additional information about the processes of development of settlements at the initial stage of the building life cycle may be used as for various types of soil the processes of settlement have been well studied and predicted. The use of the process of settlement for establishing the periodicity of examinations does not mean that only settlements are measured during such examinations. The scope and quality of examinations shall be defined in the project and operating documentation with accounting for the technical and economic performance indices. In controlling a variable parameter with a certain periodicity it is necessary to compare the measurements with the specified design or standard values and make the corresponding conclusions for adopting decisions.

Theoretical studies and experience in conducting examinations indicate that the rate of and time for stabilization of the deformation processes in buildings and structures may be varied over a wide range and substantially related with the processes of soil consolidation. The recommendations in the current normative documents on establishing the periodicity of examinations are very fuzzy and not related to the characteristics of base soils. In arranging the process of deformation control this fact may be a cause of fatal errors and affect the validity of obtained data or result in increased costs of the measuring operations.

Curves of relative subsidence and periods of its stabilization for various soil types are shown in Figure 7 and data on duration of the process of active 
subsidence and deformations are presented in Table 2 (according to the works $^{4,5}$ ).
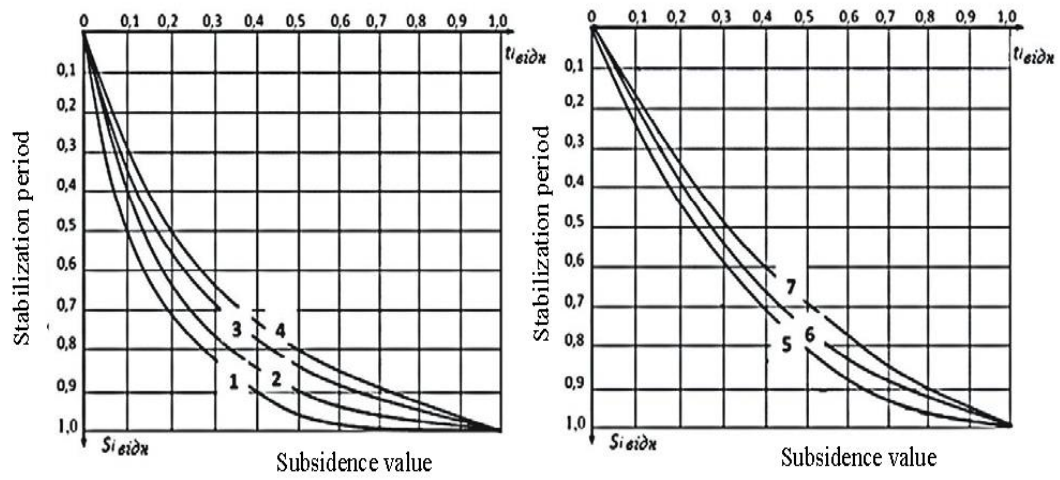

Fig. 7. Curves of relative subsidence:

1 - on gravel and coarse sands; 2 - on medium coarse sands;

3 - on fine sands; 4 - on silt soils; 5 - on sandy soils; 6 - on sandy clays;

7 - on clays; $S_{i \text { вidн. }}$ is the relative value of subsidence;

$t_{\text {ввідн. }}$ is the relative stabilization period of subsidence

Table 2

\section{Duration of active process of subsidence and deformations} (until process stabilization)

\begin{tabular}{|c|c|c|}
\hline Controlled parameters & Types of base soils & Duration $\mathrm{T}_{\text {п }}$, years \\
\hline \multirow{4}{*}{ Absolute subsidence, relative } & Gravel and coarse sands & 1 \\
\cline { 2 - 3 } difference of subsidence sizes, tilt, & Medium coarse sands & 1,5 \\
\cline { 2 - 3 } deflection of structures, buildings & Fine sands & 2 \\
\cline { 2 - 3 } and constructions due to static loads & Silt sands & 3 \\
\cline { 2 - 3 } & Sandy soils & 4 \\
\cline { 2 - 3 } & Candy clays & 10 \\
\hline
\end{tabular}

${ }^{4}$ SBC V.1.2-14-2009.Reliability and safety of building facilities assurance system. General principles of assurance of reliability and structural safety of buildings, structures, building constructions and bases. - [Enforced on 2009-12-01]. - K.: Minregionbud of Ukraine, 2009. - 44 p. - (State Building Code of Ukraine) (in Ukrainian).

5 Zhukov B.N. Manual of geodetic control of structures and equipment of industrial enterprises during their operation / B.N. Zhukov. - Novosibirsk: SGGA, 2003. - 376 p. (in Russian). 
The curves of relative subsidence may be defined by formula

$$
\mathrm{S}_{\mathrm{t}} / \mathrm{S}_{\mathrm{r}}=\left(1-\mathrm{e}^{-\mathrm{N} \cdot \mathrm{t}}\right)
$$

where $\mathrm{N}$ is the coefficient that allows for impervious blanket thickness, characteristic of relative soil compressibility and soil permeability;

$\mathrm{t}$ is time;

$\mathrm{e}$ is the natural logarithm base;

$\mathrm{S}_{\mathrm{r}}$ is the allowable limit value of deformation.

The relative subsidence rate is defined as the first derivative of the function (11)

$$
\mathrm{V}_{\mathrm{B}}=\mathrm{d} / \mathrm{dt}\left(\mathrm{S}_{\mathrm{t}} / \mathrm{S}_{\mathrm{r}}\right)=\mathrm{Ne}^{-\mathrm{Nt}}
$$

The initial rate of subsidence was used to calculate a period of instrumental examinations. This will allow us not to miss a change in parameters. At $t=0 \quad V_{B}=N$, that is the numerical value of the relative rate of subsidence equals the coefficient $\mathrm{N}$.

When the characteristics of relative soil compressibility $\mathrm{N}$ are not known and only the soil types are known the value of $\mathrm{N}$ may be determined with the use of the curves for various soil types. For this purpose for the specified time $\mathrm{t}=0,3$ the value $\mathrm{S}_{\mathrm{t}} / \mathrm{S}_{\mathrm{r}}$ shall be determined with the curves and the coefficient $\mathrm{N}$ shall be calculated by the formula. The calculated coefficients $\mathrm{N}$ for various soil types are summarized in Table 3 .

Table 3

Coefficient characterizing the capability of soils to be compressed

\begin{tabular}{|c|c|c|c|c|c|c|c|}
\hline Soil type according to Fig. $\mathbf{7}$ & $\mathbf{1}$ & $\mathbf{2}$ & $\mathbf{3}$ & $\mathbf{4}$ & $\mathbf{5}$ & $\mathbf{6}$ & $\mathbf{7}$ \\
\hline $\mathrm{N}$ & 5,71 & 4,89 & 3,80 & 3,41 & 2,89 & 2,59 & 2,18 \\
\hline
\end{tabular}


Limit deformations of bases

\begin{tabular}{|c|c|c|c|}
\hline \multirow[b]{2}{*}{ Structures } & \multicolumn{3}{|c|}{ Limit deformations } \\
\hline & $\begin{array}{c}\text { Relative difference } \\
\text { of subsidence sizes } \\
\qquad(\Delta s / L)_{u}\end{array}$ & $\begin{array}{c}\text { Tilt } \\
i_{u}\end{array}$ & $\begin{array}{c}\text { Limit } \\
\text { subsidence } \\
\mathrm{S}_{\max }, \mathbf{c m} \\
\end{array}$ \\
\hline \multicolumn{4}{|c|}{ 1. Industrial and civil single storey and multistorey buildings with full frameworks of: } \\
\hline reinforced concrete & 0,002 & - & $(10)$ \\
\hline $\begin{array}{l}\text { the same with installation of reinforced concrete } \\
\text { belts or solid floors and buildings with solid } \\
\text { structures }\end{array}$ & 0,003 & - & $(15)$ \\
\hline steel & 0,004 & - & $(15)$ \\
\hline $\begin{array}{l}\text { the same with installation of reinforced concrete } \\
\text { belts or solid floors }\end{array}$ & 0,005 & - & $(18)$ \\
\hline $\begin{array}{l}\text { 2. Buildings and structures whose structural } \\
\text { members are not affected by loads due to non- } \\
\text { uniform subsidence }\end{array}$ & 0,006 & - & (20) \\
\hline \multicolumn{4}{|c|}{ 3. Multistorey frameless buildings with bearing walls of: } \\
\hline large panels & 0,0016 & 0,005 & 12 \\
\hline $\begin{array}{l}\text { large blocks or brickwork without } \\
\text { reinforcement }\end{array}$ & 0,0020 & 0,005 & 12 \\
\hline the same with reinforcement & 0,0024 & 0,005 & 18 \\
\hline
\end{tabular}

Then we need to know an absolute rate of subsidence which depends on a duration of the process of active subsidence (Table 2) and a maximum allowable value of deformations (Tables 4 and 5) ${ }^{6,7}$.

At that the subsidence rate for a multistorey frameless building with bearing walls of large panels which is located on sandy soil equals

$$
\mathrm{V}=\mathrm{V}_{\mathrm{B}} \cdot \frac{\mathrm{S}_{\max }}{\mathrm{T}_{\text {п }}}=2,89 \frac{120}{4 \cdot 365}=0,237(\mathrm{~mm} / \mathrm{day})
$$

Since

$$
\mathrm{T}_{\text {мон. } \max }=5 \sigma_{\mathrm{в}} / \mathrm{V},
$$

${ }^{6}$ SBC V.2.1-10-2009. Construction facilities and industrial products for construction work. Bases and foundations of buildings and structures. Bases and foundations of structures. [Enforced on 2009-07-01]. - K.: Minregionbud of Ukraine, 2009. - 82 p. - (State Building Code of Ukraine) (in Ukrainian)

${ }^{7}$ DSTU B V.1.2-3:2006. Reliability and safety assurance system of construction facilities. Deflections and displacements. Design requirements. - [Enforced on 2007-01-01]. - K.: Minbud of Ukraine, 2006. - 30 p. - (National Standard of Ukraine) (in Ukrainian). 
and assuming $\sigma_{\mathrm{B}}=0,5 \mathrm{~mm}$, we obtain

$$
\mathrm{T}_{\text {мон } \max }=5 \cdot 0,5 / 0,237=10,5 \text {. }
$$

Let us assume that

$$
\mathrm{T}_{\text {мон. } \max }=10 \text { days. }
$$

The proposed method can be applied not only for defining the period of building subsidence stabilization. It allows: obtaining rather reliable characteristics of active subsidence processes, horizontal displacements and deformations; optimization of the number of measuring cycles as compared with the recommendations of the current normative documents to ensure that any changes in the geometrical parameters of building will not be missed and determination of the period of examinations for monitoring subsidence sizes, tilts and displacements with the use of equation (1) and data listed in Tables 2 and 4.

According to the recommendations, during construction under the conditions of dense development areas with existing buildings (as a rule these are the historic development areas with historical, cultural or architectural monuments) their additional deformations due to a new construction shall not exceed the limit values presented in Table 6. With the use of the data of this table a period of examinations for monitoring subsidence sizes and tilts of buildings located in the dense development areas may be determined.

Table 5

Horizontal limit displacements

\begin{tabular}{|l|c|}
\hline \multicolumn{1}{|c|}{ Buildings, walls and partitions } & $\begin{array}{c}\text { Limit } \\
\text { displacement } f_{u}\end{array}$ \\
\hline 1 Multistorey buildings & $h / 500$ \\
\hline 2 Single floor in a multistorey building: & $h_{s} / 300$ \\
\hline $\begin{array}{l}\text { a) walls and partitions made of bricks, gypsum plasterboard, } \\
\text { reinforced concrete panels }\end{array}$ & $h_{s} / 500$ \\
\hline $\begin{array}{l}\text { b) walls lined with natural stone or made of ceramic blocks } \\
\text { or glass (stained-glass) }\end{array}$ & $h_{s} / 700$ \\
\hline 3 Single storey buildings with a ceiling height $h_{s}, \mathrm{~m}: h_{s} \leq 6$ & $h_{s} / 150$ \\
$h_{s}=15$ & $h_{s} / 200$ \\
$h_{s} \geq 30$ & $h_{s} / 300$ \\
\hline
\end{tabular}


Table 6

Limit values of additional deformations

\begin{tabular}{|c|c|c|c|c|}
\hline \multirow[b]{2}{*}{ Structures } & \multirow[b]{2}{*}{$\begin{array}{l}\text { Category } \\
\text { of state }\end{array}$} & \multicolumn{3}{|c|}{ Limit deformations } \\
\hline & & $\begin{array}{c}\text { Relative } \\
\text { difference of } \\
\text { subsidence sizes } \\
(\Delta s / L)_{u} \\
\end{array}$ & Tilt $i_{u}$ & $\begin{array}{c}\text { Limit } \\
\text { subsidence } \\
\mathrm{S}_{\max }, \mathbf{c m}\end{array}$ \\
\hline \multirow{4}{*}{$\begin{array}{l}\text { Multistorey frameless buildings made } \\
\text { of large blocks or brickwork without } \\
\text { reinforcement. }\end{array}$} & I & $2 \times 10^{-3}$ & $2 \times 10^{-3}$ & 4,0 \\
\hline & II & $1 \times 10^{-3}$ & $1 \times 10^{-3}$ & 3,0 \\
\hline & III & $7 \times 10^{-4}$ & $7 \times 10^{-4}$ & 1,0 \\
\hline & IV & $4 \times 10^{-4}$ & $4 \times 10^{-4}$ & 0,4 \\
\hline \multirow{4}{*}{$\begin{array}{l}\text { Multistorey and single-storey buildings } \\
\text { of historic development or monuments } \\
\text { with bearing walls made of brickwork } \\
\text { without reinforcement. }\end{array}$} & I & - & - & - \\
\hline & II & $6 \times 10^{-4}$ & $6 \times 10^{-4}$ & 1,0 \\
\hline & III & $4 \times 10^{-4}$ & $4 \times 10^{-4}$ & 0,4 \\
\hline & IV & $1 \times 10^{-4}$ & $1 \times 10^{-4}$ & 0,2 \\
\hline
\end{tabular}

\section{Periodicity of ground water level control}

By the nature of underflooding all development areas are divided into natural or man-caused flood-prone areas and non-flood-prone areas which, in their turn, are divided by a degree of process development into potentially flood-prone or flood-prone territories and territories that demand obligatory protection. The potentially flood-prone territories are plots that are disposed to be underflooded, at which the raised level of ground water has caused or can cause the predictable worsening of serviceability of building facilities or occurrence of emergencies.

The flood-prone territories are divided by development stages of this process into:

- flood-prone territories within the plots at which the level of ground water is permanently or temporary (excluding accidental emergencies) above a limit depth or the raised level of ground water significantly worsens the serviceability of building facilities;

- flood-prone territories that demand an urgent protection of plots where an emergency has occurred due to the raised level of ground water (underflooding) and its consequences or where unsafe for health and environment conditions have been generated.

The limit depth of occurrence of ground water is an allowable maximum (according to predictions) level of ground water over the whole period of operation of the territory with buildings and structures. In designing possible changes in hydrogeological conditions at the site during construction and operation of a facility shall be accounted for. Such changes may be a result of both natural and man-caused effects. In the first case these are natural seasonal perennial variations of the level of ground water. In the second case the man-caused changes in the ground water level as well as a degree of corrosiveness of soil and their corrosive activity are possible. Possible 
changes in the ground water level in the development territory are estimated on the basis of the engineering survey data with accounting for new regimeforming factors that change a structure of water balance in the territory and are additional man-caused loads on geological environment. Figure 8 shows a classification of basic man-caused changes in the water regime and their consequences on the basis of the principle of possibility of their detection by instrumental methods.

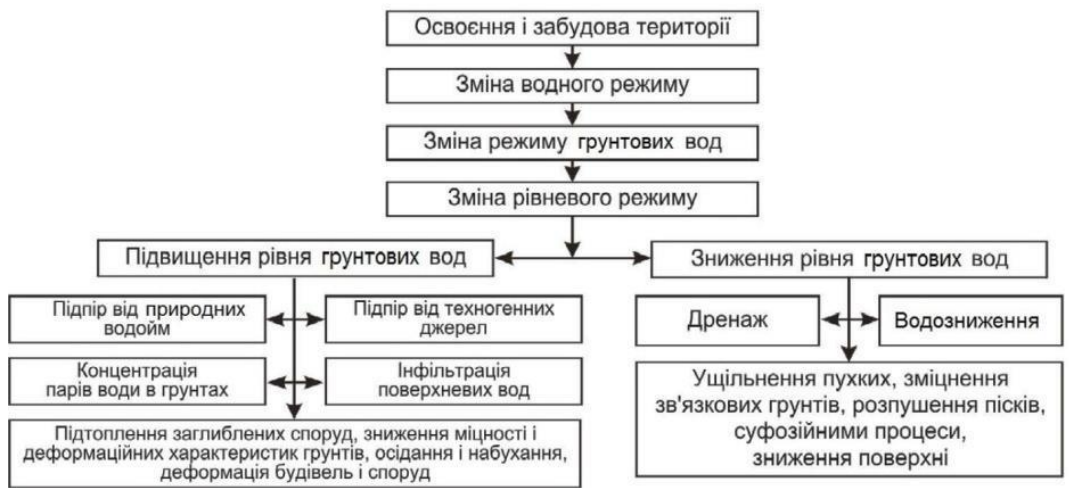

\section{Fig. 8. Classification of basic man-caused changes of the water regime and their consequences}

In the potentially non-flood-prone territories any significant raising of soil wetness and the ground water level (GWL) is not observed owing to availability of well-permeable soils or relatively deep position of the ground water level and favorable man-caused conditions (insignificant barrage effect, lack of moistureproducing businesses, small leakages from utilities etc.).

The process of underflooding development has two periods:

- during the first period the ground water level raises or soil wetness increases; such processes have no practical effect on the serviceability of structure that is the critical values of the ground water level (Нкр) and soil wetness (Wкр) are not still attained;

- the second period is characterized by the attained critical values Нкр and Wкр and the negative effect of underflooding on soils in bases and substructures of buildings and structures.

The rate of potential underflooding is based on the following preconditions:

- industrial businesses are classified by specific consumption of water according to their 'wet' or 'dry' processes; 
- on the basis of available data on underflooded development territories all types of soil conditions are classified according to four schemes based on the types of geological sections (Table 7).

The tendency to potential underflooding of territory is estimated by the criterion of potential underflooding

$$
\mathrm{P}=\left(\mathrm{h}_{\mathrm{e}}-\Delta \mathrm{h}\right) / \mathrm{H}_{\mathrm{\kappa p}},
$$

where $h_{e}$ is the ground water level before the occurrence of underflooding, it shall be defined according to the data of engineering survey (measured from the ground) $\mathrm{m}$;

$\Delta \mathrm{h}$ is the value of predicted raise of ground water at the specified point, it shall be defined according to data of Table 7, m;

$\mathrm{H}_{\text {кр }}$ is the critical ground water level measured from the ground.

At $\mathrm{P} \leq 1$ and $\mathrm{t}_{\mathrm{kp}} \leq \mathrm{T}_{\text {розр. }}$; $\mathrm{t}_{\mathrm{кр}}$ is the period of time for occurrence of the critical level $\mathrm{H}_{\mathrm{kp}}$ ) the territory is potentially flood-prone; at $t_{\mathrm{kp}}>\mathrm{T}_{\text {розр. }}$ it is potentially non-flood prone. The time is an indirect indicator of the rate of potential underflooding of territory and under condition that $P=1$ it is defined as $\Delta \mathrm{h}=\mathrm{h}_{\mathrm{e}}-\mathrm{H}_{\mathrm{kp}}$

Table 7

Classification of territories by hydrological zones

\begin{tabular}{|c|c|c|c|c|}
\hline $\begin{array}{l}\text { Scheme of } \\
\text { natural } \\
\text { conditions }\end{array}$ & Typical lythologic sections & $\begin{array}{c}\text { Thickness } \\
\text { of layer, } \\
\text { m }\end{array}$ & $\begin{array}{l}\text { Depth of } \\
\text { GWL, m }\end{array}$ & $\begin{array}{c}\text { Hydrological zone } \\
\text { of Ukraine }\end{array}$ \\
\hline thoth & $\begin{array}{l}\text { Layer } 1 \text { - loess loams and } \\
\text { sagging sandy soils. } \\
\text { Layer } 2 \text { - (water-tight stratum) } \\
\text { - clays, sandstones etc. }\end{array}$ & Up to 25 & 15 to 25 & $\begin{array}{l}\text { Zone of periodical } \\
\text { moistening, all territory }\end{array}$ \\
\hline 2 & $\begin{array}{l}\text { Layer } 1 \text { - sandy soils, loams } \\
\text { and alluvial-glacial sands. } \\
\text { Layer } 2 \text { - (water-tight stratum) } \\
\text { - clays, moraine clays. }\end{array}$ & Up to 15 & Up to 10 & $\begin{array}{l}\text { Zone of overmoistening, } \\
\text { the most part }\end{array}$ \\
\hline 3 & $\begin{array}{c}\text { Layer } 1 \text { - sandy clays and } \\
\text { blanket sandy soils of low } \\
\text { thickness. } \\
\text { Layer } 2 \text { - (water-tight stratum) } \\
\text { - expansive clays. }\end{array}$ & 1 to 5 & $\begin{array}{l}\text { More } \\
\text { than } 15\end{array}$ & $\begin{array}{l}\text { Zone of insufficient and } \\
\text { mixed periodical } \\
\text { moistening, eastern and } \\
\text { southern territories }\end{array}$ \\
\hline 4 & $\begin{array}{l}\text { Layer } 1 \text { - sandy clays, sandy } \\
\text { loam and silt, fine, coarse } \\
\text { sands, pebble stones. } \\
\text { Layer } 2 \text { - (water-tight stratum) } \\
\text { - bedrocks of various } \\
\text { formations. }\end{array}$ & Up to 10 & 5 to 10 & $\begin{array}{l}\text { Zone of periodical } \\
\text { moistening, the most part } \\
\text { of territory }\end{array}$ \\
\hline
\end{tabular}


Table 8 shows the rates of raising of the ground water level (GWL) therefore the value $t_{к р}$ is determined ${ }^{1}$ by relation

$$
\mathrm{t}_{\mathrm{kp}}=\Delta \mathrm{h} / \mathrm{V}
$$

Taking $t_{\mathrm{кp}}$ into account the degree of tendency to potential underflooding is specified:

- for the structures of Class I the first degree of tendency to potential underflooding (the most unsafe) - underflooding will occur within 5 years; the second degree - within 10 years; the third degree - within 15 yrs; the fourth degree - within $20 \mathrm{yrs}$; and the fifth - within 25 years.

- for the structures of Class II only the first three degrees of tendency to potential underflooding are applied.

Table 8

Types of flood-prone building facilities

\begin{tabular}{|c|c|c|c|c|c|}
\hline \multirow[b]{2}{*}{$\begin{array}{c}\text { Type of } \\
\text { underflooding }\end{array}$} & \multirow[b]{2}{*}{$\begin{array}{l}\text { Scheme of } \\
\text { natural } \\
\text { conditions }\end{array}$} & \multicolumn{4}{|c|}{ Rate of raising of ground water } \\
\hline & & $\begin{array}{l}\text { Within the } \\
\text { first } 10 \\
\text { years, } \\
\text { m/year }\end{array}$ & $\begin{array}{c}\text { Within } \\
10 \text { to } 15 \\
\text { years, } \\
\text { m/year }\end{array}$ & $\begin{array}{c}\text { Within } \\
15 \text { to } 20 \\
\text { years, } \\
\text { m/year }\end{array}$ & \begin{tabular}{|c|} 
Within \\
20 to 25 \\
years, $\mathrm{m} /$ year
\end{tabular} \\
\hline I & $\begin{array}{l}1 \\
2 \\
3 \\
\end{array}$ & 0,5 to 1 & 0,25 to 0,5 & $\begin{array}{l}0,3 \text { to } 0,6 \\
0,2 \text { to } 0,4\end{array}$ & 0,15 to 0,3 \\
\hline II & $\begin{array}{l}1 \\
2 \\
4 \\
\end{array}$ & 0,3 to 0,5 & 0,1 to 0,2 & 0,1 to 0,15 & 0,08 to 0,13 \\
\hline III & $\begin{array}{l}1 \\
2 \\
3 \\
4\end{array}$ & 0,1 to 0,3 & 0,03 to 0,1 & $\begin{array}{c}0,025 \text { to } \\
0,008\end{array}$ & 0,02 to 0,06 \\
\hline
\end{tabular}

That is, the potential underflooding of the developed territory is estimated; the quantitative estimates are made for corresponding structures when the prediction of changes in the ground water level subject to mancaused effects is made on the basis of comprehensive special studies which include an annual cycle of stationary examinations of the ground water regime.

The period of instrumental examinations of the ground water level may be defined as

$$
\mathrm{t}_{\text {мон }}=\Delta \mathrm{h}_{\mathrm{T}} / \mathrm{V}_{\max },
$$


where $\Delta \mathrm{h}_{\mathrm{T}}$ is the change in the ground water level within an accuracy of measuring devices;

$\mathrm{V}_{\max }$ is the maximum rate of raising of the ground water, $\mathrm{m} / \mathrm{year}$.

The data on period of examinations for various conditions at $\Delta \mathrm{h}_{\mathrm{T}}=2 \mathrm{~cm}$ are shown in Table 9.

Table 9

Minimum period of instrumental examinations

for various types of underflooding

\begin{tabular}{|c|c|c|c|c|}
\hline \multirow{2}{*}{$\begin{array}{c}\text { Type } \\
\text { of underflooding }\end{array}$} & \multicolumn{4}{|c|}{ Period of examinations, days } \\
\cline { 2 - 5 } & For the first 10 years & $\mathbf{1 0}$ to 15 years & $\mathbf{1 5}$ to 20 year & $\mathbf{2 0}$ to 25 years \\
\hline I & 7 & 15 & 18 & 24 \\
\hline II & 15 & 36 & 49 & 56 \\
\hline III & 24 & 73 & 91 & 122 \\
\hline
\end{tabular}

\section{Periodicity of slide control}

The following basic types of slides are defined: flow, escape, upfloat, coming out, subsiding, rarefying. In the development areas the most prevalent types are flow slides and escape slides. Slides within the areas of development and economic activities result in negative consequences. Table 10 shows the data on probabilities of slide occurrences and measures to be performed in the slide-affected area subject to the compliance of structures with requirements.

Table 10

Level of slide occurrence probability

\begin{tabular}{|c|c|c|c|}
\hline \multirow{2}{*}{ Construction facilities } & \multicolumn{3}{|c|}{$\begin{array}{l}\text { Level of risk of slide occurrence that demands decisions } \\
\text { on taking necessary measures }\end{array}$} \\
\hline & $\begin{array}{c}\text { protection of } \\
\text { structures }\end{array}$ & $\begin{array}{l}\text { protection of structures } \\
\text { or monitoring of slopes }\end{array}$ & $\begin{array}{c}\text { monitoring } \\
\text { of slopes }\end{array}$ \\
\hline $\begin{array}{c}\text { Large-scale construction } \\
\text { facilities }\end{array}$ & $>10 \%$ & - & 5 to $10 \%$ \\
\hline $\begin{array}{l}\text { Facilities of increased } \\
\text { importance }\end{array}$ & $>5 \%$ & 5 to $10 \%$ & 1 to $5 \%$ \\
\hline Very important facilities & $>1 \%$ & 1 to $5 \%$ & 0 to $1 \%$ \\
\hline
\end{tabular}

Slopes are considered stable if the stability factor $\mathrm{K}_{\mathrm{c}} \succ 1$. The value $\mathrm{K}_{\mathrm{c}}=1$ corresponds to the limit equilibrium. When buildings are located on a slope the slope stability factor shall comply with requirements

$$
\mathrm{K}_{\mathrm{c}} \geq \mathrm{K}_{\mathrm{c.доп}},
$$


where $K_{c . \partial o n}$ is the allowable value of stability factor which shall be defined at the design stage subject to loads, reliability and operating conditions.

In areas where slides are possible and the stability factor complies with the requirement $\mathrm{K}_{\mathrm{c}}>1$, the following shall be under monitoring: horizontal displacements, the ground water level and pore pressure. Periodicity of horizontal displacement control may be found from relation (13). For flow slide the maximum velocity of sliding is defined by the following formula ${ }^{8}$

$$
\mathrm{V}_{\mathrm{c}}^{\max }=\frac{\rho \cdot \mathrm{g} \cdot \mathrm{H}^{2} \cdot \sin \alpha}{2 \cdot \mu},
$$

where $\rho$ is the soil density, $\mathrm{t} / \mathrm{m}^{3}$;

$H$ is the maximum thickness of the sliding soil mass, m;

$\alpha$ is the angle of sliding surface, degree;

$\mu$ is the soil viscosity.

The average velocity value across the whole section is given by formula

$$
\mathrm{V}_{\mathrm{c}}^{\mathrm{cp}}=\frac{2}{3} \cdot \mathrm{V}_{\mathrm{c}}^{\max }
$$

The recommended approximate periods of examinations of slopes for various slide types at various values of the stability factor which have been determined on the basis of the data of earlier examinations are shown in Table 11.

Table 11

\section{Recommended approximate periods of monitoring of slopes}

\begin{tabular}{|c|c|c|}
\hline \multirow{2}{*}{$\begin{array}{c}\text { Slope stability } \\
\text { factor }\end{array}$} & \multicolumn{2}{|c|}{ Periodicity of monitoring, days } \\
\cline { 2 - 3 } & Forms of stability disturbances and slope deformations (slide types) \\
\cline { 2 - 3 } & escape & flow \\
\hline 0,7 & 7 & 10 \\
\hline 0,8 & 12 & 18 \\
\hline 0,9 & 20 & 25 \\
\hline 1,0 & 40 & 60 \\
\hline 1,1 & 60 & 100 \\
\hline 1,2 & 180 & 300 \\
\hline 1,35 & 360 & 500 \\
\hline
\end{tabular}

${ }^{8}$ Bugrov A.K. Determination of probability characteristics of soil active pressure by the Monte Carlo method [Electronic resource] / A.K. Bugrov, V.G. Shilin // Internet journal «Reconstruction of towns and geotechnical construction». - 2002. - No. 5. - Access mode: http://www.qeorec.spb.ru/maq/2002n5/index.htm. (10.10.14). - Title from a screen (in Russian). 
Since saturation of soil mass by water is a main cause of slides the monitoring of pore water pressure is necessary. In the process of design work a possible rate of pore pressure variations shall be determined. Selection of measuring means is carried out with accounting for a range of possible pressure variations and required accuracy of measurements.

Periodicity of pore pressure control may be defined as follows

$$
\mathrm{T}_{\text {мон.пор.тс }}=\Delta_{\mathrm{\mu}} / \mathrm{V}_{\text {п.в }} \text {, }
$$

where $\Delta_{д}$ is the resolving power of a pore pressure sensor;

$\mathrm{V}_{\text {п.в }}$ is the possible rate of pore pressure variations that is defined at the design stage.

\section{CONCLUSIONS}

1. Methods that may be applied for determination of a periodicity of work on performing instrumental examinations have been studied. It has been established that at present the periodicity of planned examinations is designated by analogy with the buildings which are under average operation conditions, but this method doesn't take into account the conception of class of consequences (the importance of buildings and structures) and may be used only in the period of normal operation.

2. A method of determination of the periodicity of instrumental examinations has been proposed. The method is based on comparison of controlled parameters with the design (predicted) values subject to a range of allowable possible deviations of a controlled parameter. The rate of changes in controlled parameters shall be established during designing work and adjusted as a result of examinations. The maximum allowable values of controlled parameters shall ensure a possibility to take measures for restoration of the building serviceability.

3. A method for adjusting the terms of examinations with accounting for the terms of repair and rehabilitation work has been developed. The function that relates deterioration and time has been applied. This function accounts for a great number of accidents at the initial stage of operation (the power function) as well as the rate of deterioration and the service life when the degree of building deterioration is an impact factor.

4. A method of determination of the periodicity of subsidence control operations at the initial stages of the life cycle of facilities and during their operation has been developed. In determining the periodicity of examinations the information about the process of subsidence development may be used. Studies of the process of subsidence may be used for determination of the periodicity of comprehensive examinations as such a process is an integrated analysis for establishing the categories of facility's 
technical conditions. The quantitative and qualitative aspects of examinations shall be defined in the design and operation documents subject to accounting for technical and economic indices of efficiency.

5. The period of instrumental examinations of the ground water level is established with accounting for a type of underflooding. The classification of basic man-caused changes in the water regime and their consequences has been presented for 4 types of soil conditions which are characterized by a rate of raising of the ground water level. It has been proposed to determine a period of such examinations on the basis of qualitative and quantitative estimates of a tendency to underflooding for the developed territory subject to results of comprehensive studies which comprise at least an annual cycle of stationary instrumental examinations based on predictions of the rate of changes in the ground water level and sensitivity of the measuring devices to dynamics of changes.

6. In regions where slides are possible horizontal displacements and the ground water level shall be controlled. As the presence of ground water is a main cause of land slides in addition to monitoring of horizontal displacements pore water pressure shall be monitored. Measuring devices shall be selected in accordance with the range and rate of possible changes in pore pressure.

\section{SUMMARY}

Methods of determination of the periodicity of work on performing instrumental examinations have been studied. It has been established that at present the periodicity of planned examinations is designated by analogy with the buildings which are under average operation conditions provided that their operating conditions can be maintained until the next planned examination. A method of determination of the periodicity of instrumental examinations that is based on comparison of controlled parameters with the design values has been proposed. The maximum allowable values of controlled parameters shall ensure a possibility to take measures for restoration of the building serviceability. A method for adjusting the terms of examinations with accounting for the terms of repair and rehabilitation work and physical deterioration as a function of time has been developed. The periodicity of subsidence control operations at the initial stages of the life cycle of facilities and during their operation is determined with the use of information about the process of subsidence development. The period of instrumental examinations of the ground water level is established with accounting for a type of underflooding.

It has been proposed to determine a period of such examinations on the basis of qualitative and quantitative estimates of a tendency to underflooding for the developed territory. 


\section{REFERENCES}

1. Ivanyk I.H. Principles of reconstruction of buildings and structures / I.H. Ivanyk, S.I. Vikhot', R.S. Ivannyk, Yu.Yu. Vybranets'; ed. I.H. Ivanyk. - L'viv: Publishers L'viv Politekhnika, 2010. - 276 p. (in Ukrainian).

2. Normative documents on issues of examinations, certifications, safe and reliable operation of production buildings and structures. - K.: NDIBV, 2003. - 144 p. (in Ukrainian).

3. Petrov E.G. Methods and means for making decisions in economic and technical systems / E.G. Petrov, M.V. Novozhilova, I.V. Grebennik, N.A. Sokolova; under the general editorship of E.G. Petrov. - Kherson: OLDI-plus, -2003 . -378 p. (in Russian).

4. SBC V.1.2-14-2009.Reliability and safety of building facilities assurance system. General principles of assurance of reliability and structural safety of buildings, structures, building constructions and bases. [Enforced on 2009-12-01]. - K.: Minregionbud of Ukraine, 2009. - 44 p. (State Building Code of Ukraine) (in Ukrainian).

5. Zhukov B.N. Manual of geodetic control of structures and equipment of industrial enterprises during their operation / B.N. Zhukov. - Novosibirsk: SGGA, 2003. - 376 p. (in Russian).

6. SBC V.2.1-10-2009. Construction facilities and industrial products for construction work. Bases and foundations of buildings and structures. Bases and foundations of structures. - [Enforced on 2009-07-01]. - K.: Minregionbud of Ukraine, 2009. - 82 p. - (State Building Code of Ukraine) (in Ukrainian)

7. DSTU B V.1.2-3:2006. Reliability and safety assurance system of construction facilities. Deflections and displacements. Design requirements. - [Enforced on 2007-01-01]. - K.: Minbud of Ukraine, 2006. - 30 p. - (National Standard of Ukraine) (in Ukrainian).

8. Bugrov A.K. Determination of probability characteristics of soil active pressure by the Monte Carlo method [Electronic resource] / A.K. Bugrov, V.G. Shilin // Internet journal «Reconstruction of towns and geotechnical construction». - 2002. - No. 5. - Access mode: http://www.qeorec.spb.ru/maq/2002n5/index.htm. (10.10.14). - Title from a screen (in Russian).

\section{Information about the author:} Hryhorovskyi P. Ye.,

Doctor of Technical Sciences,

First Deputy Director for Science, State Enterprise 'Research Institute of Building Production named of V.S. Balitsky' (SE 'RIBP') 51, Lobanovskyi ave., Kyiv, 03110, Ukraine 